\title{
PENINGKATAN DAYA SAING MELALUI STRATEGI PEMASARAN JAMUR TIRAM PUTIH (STUDI KASUS) DI DESA BEKUT
}

\author{
Susilawati $^{* 1}$, Erifa Syahnaz ${ }^{2}$ \\ ${ }^{1}$ Agrobisnis, Politeknik Negeri Sambas \\ ${ }^{2}$ Sistem Informasi, Politeknik Negeri Sambas \\ e-mail: ${ }^{1 *}$ shecerahceria@gmail.com
}

\begin{abstract}
One of the food sources that contains high vegetable protein is oyster mushroom. An oyster mushroom cultivation business in Bekut Village, Tebas district, Sambas was run by Mr. Agustipar since 2016. However, the fresh packaging of oyster mushroom only can be stored in short period of time. Therefore, the appropriate packaging strategy plays an important role in succeeding the marketing of oyster mushroom. The marketing strategy of oyster mushroom is influenced by internal factors (strengths and weaknesses) and external factors (opportunities and strengths). As a result, it is necessary to conduct a study on the oyster mushroom marketing strategy run by Mr. Agustipar. SWOT analysis was performed to analyze the data. It was found the internal factors such as having: sufficient capital, skilled labors, non-chemical food products, good quality products, a stable, affordable selling price, permanent consumers, the production of oyster mushroom has not met the demand, short-period time of product storage, and no intense promotion. The external factors are: the marketing opportunity is high, increasing demand of the product, consumers' loyalty, expanding marketing network, the existence of the similar business, increasing price of the raw material. Based on the result of SWOT analysis, there were oyster mushroom marketing strategies found. They are: maintaining the quality of oyster product and stable selling price, production and sales forecasting, print media, electronic media, and social media promotion, increasing product efficiency for competition, and establishing the cooperation with companies or UMKM processing oyster mushroom.
\end{abstract}

Keywords : marketing strategy, oyster mushroom, SWOT analysis

\section{PENDAHULUAN}

Menurut Cahyana (2009), Jamur tiram memiliki rasa yang enak dan gizi yang tinggi. Jamur tiram mempunyai kandungan gizi yang tinggi dibandingkan dengan jamur lain. Jamur tiram mempunyai kandungan gizi yang tinggi dibandingkan dengan jamur lain. Kandungan protein nabati pada jamur tiram bisa mencapai $10-30 \%$. Adapun kandungan gizi pada jamur tiram adalah sebagai berikut : protein $27 \%$, lemak 1,6\%, karbohidrat $58 \%$, serat $11,5 \%$, abu 9,3\%, kalori 265 Kkal. Selain itu, dijelaskan oleh Pasaribu, dkk (2002) menjelaskan selain kandungan gizinya yang tinggi, jamur tiram juga mempunyai manfaat untuk kesehatan di mana protein nabati pada jamur tiram ini tidak mengandung kolesterol sehingga dapat mencengah timbulnya penyakit darah tinggi dan jantung. 
Ditambahkan oleh Suriawiria (2000), budidaya jamur tiram di Indonesia dapat untuk memenuhi kebutuhan konsumen setiap hari. Prospek permintaan jamur tiram cukup cerah, karena masyarakat sadar akan pentingnya kesehatan, sehingga adanya permintaan pasar akan jamur tiram baik dalam dan luar negeri yang meningkat.

Salah satu usaha budidaya jamur yang sedang berkembangkan di Kabupaten Sambas adalah usaha budidaya jamur tiram milik Bapak Agustipar yang berlokasi di Desa Bekut Kecamatan Tebas Kabupaten Sambas. Usaha budidaya jamur tiram ini baru dibudidayakan oleh Bapak Agustipar pada bulan Juli tahun 2016. Jenis jamur tiram yang dibudidayakan adalah jamur tiram putih. Pada satu periode tanam, jamur tiram ini bisa dipanen setiap hari selama tiga bulan, dengan rata-rata produksi jamur tiram dalam bentuk segar sebanyak $\quad 5-8 \mathrm{~kg}$ per hari. Jamur tiram dalam bentuk segar ini dijual dengan harga Rp 35.000 per kg. Jamur tiram ini langsung dijual ke pasar di Tebas, Simpalai, Sambas, dan Pemangkat, maupun rumah makan-rumah makan yang ada di sekitar Tebas. Selain itu, ada juga pembeli yang berdomisili di sekitar lokasi budidaya datang langsung ke tempat budidaya jamur tiram ini atau memesan melalui telepon/Hp.

Mengingat budidaya jamur ini baru dikembangkan di Desa Bekut Kecamatan Tebas, di mana pembudidaya jamur tiram masih terbatas, sedangkan masyarakat di Kabupaten Sambas dan sekitarnya sudah mengenal jamur tiram sehingga permintaan jamur tiram semakin meningkat, maka usaha budidaya jamur tiram ini memberikan peluang yang cerah untuk dikembangkan. Berdasarkan hasil penelitian yang dilakukan oleh Sariasih (2013), harga jual jamur tiram putih $1 \mathrm{~kg}$ adalah $\mathrm{Rp} 20.000$, dengan hasil panen sebanyak $300 \mathrm{~kg}$ per satu kali panen. Sedangkan pada 1 baglog, bisa dipanen dari 5 -8 kali panen. Apabila diasumsikan bisa dipanen 3 kali, maka penerimaan yang diperoleh adalah $=\mathrm{Rp}$ 20.000 x $300 \mathrm{~kg} \mathrm{x} \mathrm{3,} \mathrm{sehingga} \mathrm{diperoleh} \mathrm{Rp} \mathrm{18.000.000.} \mathrm{Selain} \mathrm{itu,} \mathrm{biaya} \mathrm{produksi} \mathrm{yang} \mathrm{dikeluarkan}$ untuk budidaya 1.000 baglog jamur tiram sebanyak Rp 7.585.000, sehingga diperoleh pendapatan sebesar Rp 10.415.000, sehingga usaha budidaya untuk 1 periode tanam dengan 1.000 baglog cukup prospektif untuk dikembangkan menjadi agribisnis bagi Gapoktan Seroja I. Dari analisis usaha diketahui bahwa dalam sekali produksi atau sekitar \pm 3 hingga 5 bulan usaha budidaya jamur tiram putih dapat melewati Break Event Point (BEP).

Hal ini dijelaskan oleh Retnaningsih dan Bambang (2017), pada penelitiannya mengenai strategi pengembangan jamur tiram (Pleurotus ostreatus) di Kelompok Tani Aneka Jamur Desa Gondangmanis Kecamatan Karangpandang Kabupaten Karanganyar. Hasil penelitiannya menunjukkan bahwa alternatif strategi yang diperoleh yaitu mempertahankan dan meningkatkan kualitas produk bibit (F1), baglog dan jamur tiram; meningkatkan kualitas SDM anggota kelompok dalam penanganan pasca panen; membentuk kemitraan dengan kelompok lain atau asosiasi dengan pembuat baglog atau pembudidaya jamur sehingga tercapai kesepakatan harga; kerjasama dengan kelompok lain dalam hal keserempakan waktu untuk membuat baglog dan budidaya jamur sehingga apabila ada hama atau penyakit seluruh pembuat baglog atau pembudidaya jamur tiram tidak terserang semua; peningkatan efisiensi produksi untuk meningkatkan daya saing; dan penghematan melalui efisiensi biaya. Prioritas strategi yang diperoleh dalam pengembangan jamur tiram di kelompok tani Aneka Jamur adalah mempertahankan dan meningkatkan kualitas produk bibit (F1), baglog (media tanam) dan jamur tiram.

Oleh karena itu, dalam mengusahakan jamur tiram ini, jika pemasarannya tidak tepat, maka usaha ini akan mengalami kerugian bahkan kegagalan, sehingga pemasaran jamur tiram yang tepat sangat berperan penting guna keberhasilan usaha ini. Pemasaran jamur tiram ini dipengaruhi oleh faktorfaktor internal (kekuatan dan kelemahan) dan eksternal (peluang dan ancaman). Berdasarkan penjelasan tersebut maka, perlu diteliti peningkatan daya saing melalui strategi pemasaran jamur tiram putih di Desa Bekut Kecamatan Tebas Kabupaten Sambas. 


\section{METODE PENELITIAN}

Adapun metode penelitian ini merupakan metode penelitian deskriptif kualitatif. Sedangkan metode pengumpulan data yang digunakan pada penelitian ini berupa wawancara dengan bantuan pedoman wawancara pertanyaan (kuisioner). Penelitian ini merupakan penelitian studi kasus yang objek penelitiannya adalah Bapak Agustipar selaku pemilik usaha budidaya jamur tiram, yang berlokasi di Jalan Dhalil, Desa Bekut Kecamatan Tebas Kabupaten Sambas. Analisis data yang digunakan pada penelitian ini berupa: Matriks IFE dan EFE, kemudian dilanjutkan dengan analisis SWOT.

\section{HASIL DAN PEMBAHASAN}

Adapun hasil penelitian mengenai faktor-faktor yang mempengaruhi pemasaran jamur tiram adalah sebagai berikut :

\section{Faktor internal}

Faktor internal terdiri dari dua aspek, yaitu :

a. Kekuatan

Aspek kekuatan dari pemasaran jamur tiram terdiri dari :

1) Memiliki modal yang cukup

2) Tenaga kerja yang terampil

3) Memiliki kendaraan pemasaran sendiri

4) Produk tidak menggunakan bahan kimia

5) Kualitas produksi jamur tiram baik

6) Harga jual jamur tiram stabil dan terjangkau bagi konsumen

7) Memiliki konsumen tetap atau pelanggan tetap

b. Kelemahan

Aspek kelemahan dari pemasaran jamur tiram, terdiri dari :

1) Jumlah produksi jamur tiram belum mencukupi permintaan

2) Kualitas produk jamur tiram tidak tahan lama

3) Jumlah kendaraan untuk pemasaran sedikit

4) Belum ada promosi yang intens

\section{Faktor eksternal}

Faktor eksternal terdiri dari dua aspek, yaitu :

a. Peluang

Aspek peluang dari pemasaran jamur tiram terdiri dari :

1) Peluang pasar jamur tiram yang masih besar

2) Permintaan konsumen akan jamur tiram yang meningkat

3) Loyalitas konsumen

4) Dapat memperluas jaringan pemasaran

b. Ancaman

Aspek ancaman dari pemasaran jamur tiram terdiri dari :

1) Munculnya usaha sejenis

2) Kenaikan harga bahan baku

\section{Analisis Data Jamur Tiram}

a. Matriks Internal Faktor Evaluation (IFE)

Berdasarkan hasil wawancara mengenai faktor internal dari pemasaran jamur tiram milik Bapak Agustipar, maka Maktriks Internal Faktor Evaluation (IFE) dapat dilihat di Tabel 1. 
Tabel 1. Maktriks Internal Faktor Evaluation (IFE)

\begin{tabular}{|c|c|c|c|c|}
\hline \multicolumn{2}{|c|}{ Kekuatan } & \multirow{2}{*}{$\frac{\text { Rating }}{4}$} & \multirow{2}{*}{$\begin{array}{c}\text { Bobot } \\
0,096\end{array}$} & \multirow{2}{*}{$\begin{array}{l}\text { Skor } \\
0,385\end{array}$} \\
\hline 1 & Memiliki modal yang cukup & & & \\
\hline 2 & Tenaga kerja yang terampil & 4 & 0,076 & 0,305 \\
\hline 3 & $\begin{array}{l}\text { Memiliki kendaraan pemasaran } \\
\text { sendiri }\end{array}$ & 3 & 0,078 & 0,233 \\
\hline 4 & $\begin{array}{l}\text { Produk tidak menggunakan bahan } \\
\text { kimia }\end{array}$ & 4 & 0,100 & 0,402 \\
\hline 5 & Kualitas produk jamur tiram baik & 4 & 0,102 & 0,408 \\
\hline 6 & $\begin{array}{l}\text { Harga jual jamur tiram stabil dan } \\
\text { terjangkau oleh konsumen }\end{array}$ & 3 & 0,087 & 0,260 \\
\hline \multirow[t]{2}{*}{7} & $\begin{array}{l}\text { Memiliki konsumen tetap/pelanggan } \\
\text { tetap }\end{array}$ & 4 & 0,097 & 0,387 \\
\hline & \multicolumn{2}{|c|}{ Jumlah Bobot dan Skor dari Faktor Kekuatan } & $\mathbf{0 , 6 3 6}$ & 2,380 \\
\hline \multicolumn{2}{|c|}{ Kelemahan } & Rating & Bobot & Skor \\
\hline 1 & $\begin{array}{l}\text { Jumlah produksi jamur tiram belum } \\
\text { mencukupi permintaan }\end{array}$ & 4 & 0,092 & 0,367 \\
\hline 2 & $\begin{array}{l}\text { Kualitas produk jamur tiram tidak } \\
\text { tahan lama }\end{array}$ & 3 & 0,093 & 0,280 \\
\hline 3 & $\begin{array}{l}\text { Jumlah kendaraan untuk pemasaran } \\
\text { sedikit }\end{array}$ & 3 & 0,088 & 0,264 \\
\hline 4 & Belum ada promosi yang intens & 3 & 0,091 & 0,273 \\
\hline \multicolumn{3}{|c|}{ Jumlah Bobot dan Skor dari Faktor Kelemahan } & 0,364 & 1,184 \\
\hline \multicolumn{3}{|c|}{ Jumlah Bobot Faktor Internal } & $\mathbf{1 , 0 0 0}$ & 3,563 \\
\hline
\end{tabular}

Sumber : Analisis Data Primer, 2019

Berdasarkan analisis matriks IFE pada Tabel 1, skor yang diperoleh adalah 3,563. Skor dengan nilai 3,563 menunjukkan bahwa usaha pemasaran jamur tiram milik Bapak Agustipar ini berada pada posisi yang kuat. Hasil pembobotan faktor internal yang paling tinggi pada kekuatan adalah kualitas produk jamur tiram baik, dengan skor 0,408. Kualitas jamur tiram yang baik. Sedangkan hasil pembobotan faktor internal yang paling tinggi pada kelemahan adalah jumlah produksi jamur tiram belum mencukupi permintaan, dengan skor 0,367 . Konsumen tetap atau pelanggan tetap jamur tiram ini hanya diberikan batasan dalam pembelian jamur tiram, yaitu maksimal $2 \mathrm{~kg}$ per pelanggan tetap. Hal ini dikarenakan produksi jamur tiram belum mencukupi permintaan konsumen. oleh karena itu, diperlukan peningkatan jumlah produksi jamur tiram.

b. Matriks Eksternal Faktor Evaluation (EFE)

Berdasarkan hasil wawancara mengenai faktor eksternal dari pemasaran jamur tiram milik Bapak Agustipar, maka Maktriks Eksternal Faktor Evaluation (EFE) dapat dilihat pada Tabel 2. 
Tabel 2. Maktriks Eksternal Faktor Evaluation (EFE)

\begin{tabular}{|c|c|c|c|c|}
\hline \multicolumn{2}{|r|}{ Faktor Eksternal } & \multirow{2}{*}{$\begin{array}{c}\text { Rating } \\
4\end{array}$} & \multirow{2}{*}{$\begin{array}{c}\text { Bobot } \\
0,178\end{array}$} & \multirow{2}{*}{$\begin{array}{l}\text { Skor } \\
0,713\end{array}$} \\
\hline 1 & $\begin{array}{l}\text { Peluang pasar jamur tiram yang masih } \\
\text { besar }\end{array}$ & & & \\
\hline 2 & $\begin{array}{l}\text { Permintaan konsumen akan jamur tiram } \\
\text { yang meningkat }\end{array}$ & 4 & 0,171 & 0,682 \\
\hline 3 & Loyalitas konsumen & 3 & 0,188 & 0,565 \\
\hline \multirow[t]{2}{*}{4} & Dapat memperluas jaringan pemasaran & 4 & 0,176 & 0,703 \\
\hline & Jumlah Bobot dan Skor dari Fa & r Peluang & $\mathbf{0 , 7 1 3}$ & 2,663 \\
\hline \multicolumn{2}{|c|}{ Ancaman } & Rating & Bobot & Skor \\
\hline 1 & Munculnya usaha sejenis & 4 & 0,155 & 0,620 \\
\hline \multirow[t]{3}{*}{2} & Kenaikan harga bahan baku & 4 & 0,132 & 0,529 \\
\hline & Jumlah Bobot dan Skor dari Fak & Ancaman & $\mathbf{0 , 2 8 7}$ & 1,149 \\
\hline & Jumlah Bobot Fakt & Ksternal & 1,000 & 3,812 \\
\hline
\end{tabular}

Sumber: Analisis Data Primer, 2019

Berdasarkan analisis matriks EFE pada Tabel 2, skor yang diperoleh adalah 3,812. Skor dengan nilai 3,812 ini menunjukkan bahwa usaha pemasaran jamur tiram milik Bapak Agustipar ini berada pada posisi yang kuat. Hasil pembobotan faktor internal yang paling tinggi pada peluang adalah peluang pasar jamur tiram masih besar, dengan skor 0,713. Sedangkan hasil pembobotan faktor internal yang paling tinggi pada ancaman adalah munculnya usaha sejenis, dengan skor 0,620.

c. Analisis Matriks SWOT pada Pemasaran Jamur Tiram Analisis matriks SWOT ini menggunakan hasil analisis yang diperoleh dari matriks IFE dan EFE. Berdasarkan matriks IFE dan EFE, maka dapat digambarkan matriks SWOT dari pemasaran jamur tiram pada Gambar 1 . 


\begin{tabular}{|c|c|c|}
\hline Eksternal & \begin{tabular}{|l}
\multicolumn{2}{c}{ KEKUATAN (S) } \\
1. \\
Memiliki modal yang cukup \\
(S1) \\
2. Tenaga kerja yang terampil \\
(S2) \\
3. Memiliki kendaraan \\
pemasaran sendiri (S3) \\
4. Produk tidak menggunakan \\
bahan kimia (S4) \\
5. $\begin{array}{l}\text { Kualitas produksi jamur } \\
\text { tiram baik (S5) }\end{array}$ \\
6. $\begin{array}{l}\text { Harga jual jamur tiram stabil } \\
\text { dan terjangkau }\end{array}$ \\
konsumen (S6) \\
Memiliki konsumen \\
tetap/penggan tetap (S7)
\end{tabular} & \begin{tabular}{|ll}
\multicolumn{1}{|c}{ KELEMAHAN (W) } \\
1. \\
Jumlah produksi jamur \\
tiram belum mencukupi \\
(W1) \\
2.
\end{tabular} \\
\hline \begin{tabular}{|ll}
\multicolumn{1}{|c}{ PELUANG (O) } \\
1. & Peluang pasar jamur tiram \\
& yang masih besar $(\mathrm{O} 1)$ \\
2. & Permintaan konsumen akan \\
& jamur tiram yang meningkat \\
$(\mathrm{O} 2)$
\end{tabular} & $\begin{array}{ll}\text { 1. } & \text { Menjaga dan } \\
\text { mempertahankan kualitas } \\
\text { jamur tiram serta harga jual } \\
\text { produk jamur tiram yang } \\
\text { stabil (S1, S2, S4, S5,S6, S7, } \\
\text { O1, O2, O3, O4) } \\
\text { 2. } \\
\text { Adanya peramalan produksi } \\
\text { dan penjualan (S6, S7, O1, } \\
\text { O2, O4) }\end{array}$ & $\begin{array}{l}\text { Meningkatkan promosi } \\
\text { pada media cetak, media } \\
\text { elektronik, maupun media } \\
\text { sosial (W4, O1, O2, O4) }\end{array}$ \\
\hline $\begin{array}{l}\text { ANCAMAN(T) } \\
\text { 1. Munculnya usaha sejenis } \\
\text { (T1) } \\
\text { 2. Kenaikan harga bahan baku } \\
\text { (T2) }\end{array}$ & $\begin{array}{l}\text { Peningkatan efisiensi } \\
\text { produksi untuk } \\
\text { meningkatkan daya saing } \\
(\mathrm{S} 1, \mathrm{~S} 2, \mathrm{~S} 3, \mathrm{~S} 4, \mathrm{~S} 5, \mathrm{~T} 1)\end{array}$ & $\begin{array}{l}\text { Menjalin kerjasama dengan } \\
\text { perusahaan / UMKM yang } \\
\text { mengolah hasil jamur tiram } \\
(\mathrm{W} 2, \mathrm{~T} 1)\end{array}$ \\
\hline
\end{tabular}

\section{Gambar 1. Matriks SWOT}

Berdasarkan analisis SWOT pada Gambar 1. terdapat alternatif strategi yang akan digunakan oleh Bapak Agustipar pada pemasaran jamur tiram, yaitu:

\section{Strategi Strength-Opportunity (SO)}

Strategi SO adalah strategi yang menggunakan kekuatan internal untuk memanfaatkan peluang eksternal. Adapun alternatif strategi SO yang dapat dirumuskan yaitu :

1) Menjaga dan mempertahankan kualitas jamur tiram serta harga jual produk jamur tiram yang stabil

2) Adanya peramalan produksi dan penjualan

\section{Strategi Weakness-Opportunity (WO)}

Strategi WO adalah strategi untuk meminimalkan kelemahan yang ada untuk memanfaatkan peluang eksternal. Strategi WO yang dapat dirumuskan dengan cara meningkatkan promosi pada media cetak, media elektronik, maupun media social.

\section{Strategi Strength-Threat (ST)}

Strategi Strength-Threat (ST) adalah strategi untuk mengoptimalkan kekuatan internal yang 
dimiliki dalam menghindari ancaman. Strategi ST yang dapat dirumuskan yaitu peningkatan efisiensi produksi untuk meningkatkan daya saing.

\section{Strategi Weakness- Threat (WT)}

Strategi WT adalah strategi untuk meminimalkan kelemahan internal dan menghindari ancaman eksternal. Strategi WT yang dapat dirumuskan dengan cara menjalin kerjasama dengan perusahaan / UMKM yang mengolah hasil jamur tiram.

\section{KESIMPULAN DAN SARAN}

\section{Kesimpulan}

Adapun kesimpulan yang diperoleh dari penelitian mengenai peningkatan daya saing melalui strategi pemasaran jamur tiram putih di Desa Bekut, yaitu:

1. Faktor-faktor internal dari pemasaran jamur tiram adalah : memiliki modal, tenaga kerja yang terampil, produk tidak menggunakan bahan kimia, kualitas produksi jamur tiram baik, harga jual jamur tiram stabil dan terjangkau, memiliki konsumen tetap, jumlah produksi jamur tiram belum mencukupi permintaan, kualitas produk jamur tiram tidak tahan lama, dan belum ada promosi yang intens.

2. Faktor-faktor eksternal adalah: peluang pasar jamur tiram yang masih besar, permintaan konsumen akan jamur tiram yang meningkat, loyalitas konsumen, dapat memperluas jaringan pemasaran, munculnya usaha sejenis, dan kenaikan harga bahan baku.

3. Strategi pemasaran jamur tiram di Desa Bekut yaitu : menjaga dan mempertahankan kualitas jamur tiram serta harga jual produk jamur tiram yang stabil, adanya peramalan produksi dan penjualan, meningkatkan promosi pada media cetak, media elektronik, maupun media sosial, peningkatan efisiensi produksi untuk meningkatkan daya saing, dan menjalin kerjasama dengan perusahaan / UMKM yang mengolah hasil jamur tiram.

\section{Saran}

Saran dan masukan dari penelitian tentang strategi pemasaran jamur tiram ini kepada Bapak Agustipar selaku pemilik pondok jamur tiram yaitu : diharapkan agar dapat menerapkan strategi pemasaran yang diperoleh dari hasil analisis SWOT yang telah diteliti. Hal ini bertujuan untuk meningkatkan daya saing jamur tiram melalui peningkatan volume penjualan maupun pemasaran jamur tiram sehingga jamur tiram dapat memenuhi permintaan konsumen dan pasar, baik dalam bentuk jamur tiram segar ataupun olahannya.

\section{DAFTAR PUSTAKA}

Cahyana, 2009. Jamur Tiram. Penebar Swadaya. Jakarta.

Pasaribu, T., Permana, E.R. Alda. 2002. Aneka Jamur Unggulan yang Menembus Pasar. Grasindo. Jakarta.

Retnaningsih, R., Bambang N.C. 2017. Strategi Pengembangan Jamur Tiram di Kelompok Tani Aneka Jamur Desa Gondangmanis Kecamatan Karangpandang Kabupaten 
Karanganyar. Jurnal SEPA Vol. 14 No.1 September 2017 Hal:61-68. ISSN: 1829-9946. Universitas Veteran Bangun Nusantara Sukoharjo. Sukoharjo.

Sariasih, Yenny. 2013. Pengembangan Budidaya Jamur Tiram Putih sebagai Agribisnis Prospektif bagi Gapoktan Seroja I Kandang Limun Bengkulu. Jurnal Agrisep Vol. 13 No. 1 Maret 2013 Hal: 11-18. ISSN: 1412-8837. Fakultas Pertanian Universitas Bengkulu. Bengkulu.

Suriawiria, U. 2000. Bioteknologi Perjamuran. Percetakan Angkasa. Bandung. 